\title{
The Gosudar and His Covert Court: Sistema, Autocracy, and Russia's Inability to Democratize
}

\author{
Emmalee Valentine
}

Any question about Russian President Vladimir Putin's style of rule can be answered by examining both Russia's past as well as the informal governmental conventions that have historically prevailed. The purpose of this article is to juxtapose the theses of two essential academics: the late historian Richard Pipes's verdict on Russian autocracy in Russian Conservatism and Its Critics: A Study in Political Culture (2005) and the concept of sistema, authored by political sociologist Alena Ledeneva in Can Russia Modernise? Sistema, Power Networks and Informal Governance (2013). "Why can't Russia democratize?" is an enduring question. This article will provide a thorough analysis of each individual work, and conjoin the relevant concepts presented in either title to find a possible answer to this question. The examined work of Richard Pipes will best illustrate the relevant themes of Russian history, even with details one might normally surmise as minute, such as Russia's geography and the question of property rights. Sistema is introduced by Alena Ledeneva as an informal governmental structure which heavily dictates the customs of ruling administrations. The conclusion that this article hopes to illustrate by bridging the theories presented in the two aforementioned titles is that Russia's inability to democratize is the consequence of both its history and the underhanded structure of its current state, which has endured throughout all forms of government - past and present alike.

Keywords: Putin, Russia, sistema, Russian Federation, autocracy

\section{| Introduction}

From the mid-fifteenth century until as late as 1917, Russian tsars were otherwise known as the gosudari. In the Russian language, gosudar is "the personal power of a free man over an unfree one, over a slave" (Pipes 14). By this definition, not only was the tsar a king, but he was also a slave-master. While many cultures throughout history accepted the practice of slavery, it would be hard to find a country outside of Russia which also allowed its entire populace to be enslaved to the sole will of its leader. While serfdom was supposedly eradicated in 1861, this did not entirely end the enslavement of the Russian people to the will of the Russian state. Moreover, it could 
be argued that not even the Bolshevik revolution or the birth of the Soviet Union ended the enslavement of the Russian people. The differences between an imperial dynasty and a communist regime are myriad; however, they could certainly be argued to have been largely superficial. The paint coating the Russian state was new, but deep within its core, the Russian people continued to lack autonomy over themselves. The state was still in full control.

The Soviet Union fell near the end of the twentieth century. At the birth of the Russian Federation, everything looked as if it would be different. Democracy was within grasp for the Russian people. And yet, looking at Russia today, one could easily conclude that Russia is not a democracy which we will define, for the purposes of this paper, as a governmental system which is ruled by its people, and in which all members of the population have the opportunity to participate in state affairs, either by becoming elected officials or by voting. Historically, Russia has failed to form a democratic system. At the beginning, this was thanks to an outright rejection of the concept of democracy. Today, however, it seems that Russia pretends to act as if it were democratic, while still refusing to actually implement an honest and true democratic system.

The question of why this remains to be the case in the twenty-first century is perhaps a question that is difficult to answer. Russia's behavior remains elusive and can oftentimes be difficult to interpret. However, two individuals in particular can be credited for providing separate but equally adequate explanations.

The first of the two authors considered in this article's comparison is the late historian Richard Pipes, a professor of Russian and Soviet history at Harvard University. Pipes is responsible for many publications examining Russian political behavior, though his 2006 work titled Russian Conservatism and Its Critics: A Study in Political Culture best answers the question raised above. In this work, Pipes examines the reason Russia has continued to choose unlimited autocracy since the Middle Ages. "It is my conviction," he writes in the introduction, "that Russian political institutions and practices across the ages engendered a singular chasm between rulers and ruled" (xv). The second individual who offers a significant breakthrough on this subject is Alena Ledeneva, a professor of Politics and Society at the School of Slavonic and East European Studies in London. Ledeneva is a renowned expert internationally on Russia's "informal governance" system. In Can Russia Modernise? Sistema, Power Networks and Informal Governance, Ledeneva outlines the concept of the Russian sistema, an informal system which has influenced how Russia is governed for a length of time, which long precedes Putin's presidency, and even the Soviet Union. "[Sistema] serves to glue society together, to distribute resources and to ensure its own reproduction. The central argument of this book," Ledeneva writes, "is that Russia cannot modernise without modernising the network-based governance patterns referred to as sistema" (Ledeneva 2).

The two works would not automatically be seen as complementary to one another; Richard Pipes's work is staunchly historical, and Alena Ledeneva relies on figures, surveys, and the Putin administration, which is far from being something of the past. However, they do complement one another in the context of this question alone. The answer to the question of why Russia can't democratize can be found by uniting the schools of thought from both Pipes, whose work thoroughly explains the reason for lasting autocracy in Russian governance styles, and Ledeneva, who intensely investigates the deep roots of sistema under which Russia seems to be eternally doom-driven.

\section{| Sowing the Seeds of Autocracy - Geography, Property \& Power}

The concept of sistema is not the subject of Pipes's work at all. Pipes seeks not to explicitly name the reason for Russia's lack of a democratic governance style, but to examine the ties between Russian autocracy and conservative thought: 
The dominant strain in Russian political thought throughout history has been a conservatism that insisted on strong, centralized authority, unrestrained either by law or parliament. Its central argument was succinctly stated in 1810-11 by Nikolai Karamzin: "Autocracy has founded and resuscitated Russia. Any change in her political constitution has led in the past and must lead in the future to her perdition." (Pipes 1)

Similar to other states in Europe and in other corners of the world, Russia has seen a handful of different governance styles. Russia was not always ruled by an imperial dynasty - it also was subject to a communist regime, and currently, functions as something entirely different. However, one thing has remained steady throughout the many different faces of the Russian state - autocracy. Pipes examines many different reasons for both the origin of Russian autocracy and the reason it stayed put throughout the extent of Russia's existence. The initial rationale can be defined by three factors: the nature by which Russia developed, its culture, and its geography (1).

European monarchies were shaped also by three different elements, which are quite different - the Roman Empire's legacy, the culture of the several tribes from which European states were formed, as well as the institution of the Catholic Church (1). Culturally, Russia was dissimilar for many reasons, not the least of which being the domination of the Mongols over Russia in its early life (11). Another large factor of its cultural difference could be found in the Orthodox religion: "The concept of 'common good' was missing from the Byzantine vocabulary. A bad, unjust ruler was, in its view, not a tyrant but God's instrument in punishing human iniquity and as such, someone who had to be unreservedly obeyed . . . to the extent that kings bore responsibility for their actions, they were accountable to God, not to man" (13).

Russia's geography played another important factor in the birth of its lasting autocratic system. Russia by and large was not guarded by natural borders such as mountains, seas or rivers, and its territory was immense (9). As a result, excessive raids were the norm - the most famous and enduring example in early Kievan Rus' history being the Mongol invasion, which led to an age of Mongol rule over Kievan Rus' until arguably as late as 1480 (Moss 67). Consequently, the resulting territorial insecurity felt by Russian rulers led to mass militarization of every institution which did exist (Pipes 10).

Pipes goes further than only examining the origins of Russian autocracy, of course - a large portion of the text is dedicated to illustrating the unique political behaviors which led to its lasting durability. Perhaps the largest contributing factor was the lack of property rights held by the serf class. This was partially due to the expansive geography and the lack of land scarcity for the early Russian peoples (10); however, the inability to own land was also due to the ruling class's determination to bind the peasantry to the land (19). Conversely, European nations even in their earliest stage granted common peoples the rights to possess private property:

The patrimonial state defined Russian absolutism in terms very different from those familiar in the West and more akin to those observed in the Orient. Here, rulers not only were free to legislate and tax at will, as were Philip II of Spain or Louis XIV, but confronted neither private property nor established social estates, which, by their very existence, set limits to their authority. Nor did Russia's rulers have to contend with the notion of "society" as a partner or have the church require them to rule for society's benefit. (23)

Patrimonialism, furthermore, became the favored method of rule of the Russian tsars. "You have attacked both the government and me," Pipes quotes Nicholas I to have once said, "because the government and I are one and the same; although I heard that you separate me from the government, I don't accept this" (180). While forms of democratic institutions did appear to exist even during the imperial dynasty, such as the Boyar Duma, and the Senate, these were not honest methods of checks and balances, but rather blank and empty formalities which many of the participants barely bothered to earnestly participate in (20). 


\section{THE GOSUDAR AND HIS COVERT COURT: SISTEMA, AUTOCRACY, AND RUSSIA'S INABILITY TO DEMOCRATIZE}

Russia developed heavy nationalist sentiments particularly after the emancipation of the serfs - nationalism replaced serfdom, and this only fueled the need for an autocratic system (119). After the Polish rebellion of 1863, Russia was shaken:

[The rebellion] was interpreted not as a legitimate effort of an ancient people to recover their independence but as Europe's assault on Russia. It contributed greatly to the emergence of an extreme nationalism and to the sense that only autocracy could preserve Russia's integrity. Such was the new conservatism: nationalistic and populist, anti-Western, frightened for Russia's future and increasingly defensive. (122)

All these elements combined, of course, with the Russian state's preexisting insecurities would create a perfect storm that would only further justify Russia's supposed need for total control in the minds of its rulers.

\section{The Clandestine Government Behind the Kremlin Curtains}

Alena Ledeneva does not provide long-winded accounts of historical explanation for Russia's political behavior. However, similar to Pipes, she explains Russian political trends concisely. Ledeneva's approach can be seen as an answer to the question that Pipes is barely short of asking: the question of Russia's inability to democratize, and the reason why Russia, year after year, continues to choose autocratic rule. Ledeneva, instead of focusing on autocracy, chooses to define this trend with the concept of sistema. Sistema is not something which can be defined dryly. Ledeneva writes that it can be most simply assumed as a "system of governance" (19), though Russian sistema is much more complex. It did not begin with the birth of the Soviet Union, or with its death. Not only is it difficult to pinpoint the historical origins of sistema, perhaps thanks to its elusive nature, but it is also difficult to define. However, definition or no definition, insiders of the Russian state "know an elephant" when they come across one, according to the author (19). Take, for instance, the response of one anonymous insider from Ledeneva's research:

This is not a system that you can choose to join or not - you fall into it from the moment you are born. There are of course also mechanisms to recruit to discipline and help reduce it. In the Soviet Union, all people were corporate (korporativnye), nuts and bolts of the same machine, but some new features emerged in the post-Soviet period. In the Soviet Union there was more or less a consolidated state, whereas now it is impossible to disentangle the state from a network of private interests. Modern clans are complex. It is not always clear who is on top. A kompromat attack [leak of compromising information] can come from within the same clan. Perhaps this complexity is not a new quality after all. Perhaps it was also complex in the past, only we don't know it well so the Soviet sistema comes across as more consistent. (19)

Sistema defines many attributes of Russian political culture. It consists of informal governance, which is a governance that is not dictated by the rule of law, or defined clearly and transparently by solid, public institutions. The practice of informal governance is not only a gatekeeper of opportunities of power (12), but it is also a "highly personalized form of checks and balances" (217) - the informal governance keeps its actors in check, while also safekeeping the raw power it provides its beneficiaries from public scrutiny. Ledeneva asserts that said informal practices are "not automatically detrimental" (11) - while they negatively affect Russia's ability to behave as a proper democracy, they do serve their own function in Russia's political and economic development. Sistema, for all of its faults, glues Russia together, and is not entirely negative. Perhaps it restrains Russia from finally breaking from the chains of "pre-modernism," but sistema does indeed serve to glue the society together, as well as "distribute resources and ensure its own reproduction" (2). 
However, the existence of sistema does indeed serve as a large contributor to why Russia cannot function as a democracy. Without the proper existence of checks and balances, formality, and impartial law enforcement (23), the Russian people do not have adequate liberty. Unfortunately, due to the complexities of sistema, it is not something which can be easily shed from the Russian political machine.

The Putin administration is not the first administration to adopt sistema and make it its own, and it likely will not be the last. Putin is not expressly a tsar, and Russian citizens are allowed to purchase property, choose their career, and practice religion. However, the echoes of both the Soviet Union as well as the imperialist dynasty pre-1917 are loudly heard. Instead of land being a privilege largely unattainable to the common Russian citizen, wealth is a privilege. The globalization and free market have both provided new opportunities to the ruling class to remain in power - "the key difference in Putin's sistema is its orientation on wealth . . . the power networks that used to be aimed at obtaining privileges have become oriented towards monetary income and capital" (248). Additionally, "favors of access" play a similar role (12). Property rights supposedly do exist, though the Putinist sistema causes them to "remain weak" (233).

How could a government which maintains a sistema such as Putin's - which only offers shaky stability on property rights at best, which rules through secret power networks, underhanded deals, and fixed elections - be seen as a democracy? It cannot, because sistema is not something that can exist simultaneously with a democratic government. On paper, President Putin would not admit to being an authoritarian ruler, but it is clear to his own people as well as anybody who pays close attention to the Kremlin that he is nothing less than a twenty-first century tsar.

\section{Conclusion}

While Ledeneva does not write of sistema being expressly a feature of autocratic rule - nor would it be classified exclusively as such - examining both her illustration of sistema and its nature in conjunction with Pipes's examination of autocracy is largely beneficial when viewing the problem of democratic governance in the Russian state, both historically and currently. Ledeneva emphasizes the use of informal governance and power networks, and while Pipes does not explicitly mention this factor in the ruling class, he can be seen citing an example of something similar from a time as early as the imperial dynasty:

On ascending the throne, Alexander invited for regular consultation four friends who shared his political ideals and with whom he had frequent intimate discussions as successor to the throne until his father, Paul I, dispersed them ...the four friends used to meet for supper at the imperial palace two or three times a week and then withdraw with the tsar to a nearby salon for freeranging discussions. The group, which came to be popularly known as the Unofficial Committee . .. followed no set agenda: subjects came up at random. (Pipes 80)

Additionally, the issue of a fraudulent appearance of democracy is reviewed in both texts. Pipes's examination of the Boyar Duma and its inability to function in the manner which it is purposed (19) can be seen explained by the "gaps" which Ledeneva lists in the introduction of her work (Ledeneva 3). The lack of property rights in imperial Russia (Pipes 10) thankfully is not an issue that explicitly persists today, but as cited earlier, Putin's sistema does not offer Russian citizens anything better than a "weak" version of the right to own property at best (Ledeneva 133-4).

Returning to the question of democratization, both scholars answer it differently, and perhaps viewing one or the other exclusively would only provide an incomplete view of the truth. Pipes examines the autocratic roots of Russian political culture and their lasting longevity, though he spends little time if any on the application of his findings on current Russian political behavior. Ledeneva illustrates the entirely new concept of sistema, the messy nature of informal governance and the "modernization trap of informality" (252) - which is how she explains 
the difficulties that Russia would inevitably face if it ever did truly attempt to rise above sistema's restrictions.

Together, the two titles give a clearer image to those asking why Russia is unable to flourish as a democratic state. The word for "state" in Russian is gosudarstvo. Basic, elementary understanding of the Russian language provides the insight that Russian words are often derived from roots. It is a very fitting word: the core objective of the Russian state, as portrayed time and time again, is defined no more elaborately than by the root of the word for state itself. The state has yet to exist for the sake of its people. Its people still exist for the sake of the state. Moreover, Putin, whether he would admit to it truthfully or not, does certainly fit under the definition of a gosudar himself. He too has failed to exist for the sake of his people. And until the Russian people can inaugurate an administration that does not enslave them to the ever-enduring sistema, Russia will not be able to rise to be the democracy that its people and the Western world desire it to be. 


\section{| References}

Ledeneva, Alena V. Can Russia Modernise? Sistema, Power Networks and Informal Governance. Cambridge University Press, 2013.

Moss, Walter G. A History of Russia: Volume I: To 1917. Anthem Press, 2005.

Pipes, Richard. Russian Conservatism and Its Critics: A Study in Political Culture. Yale University Press, 2005. 